\title{
Emission of Liquid-phase Polycyclic Aromatic Hydrocarbons from a Direct Methanol Fuel Cell
}

\author{
Kuo-Lin Huang ${ }^{*}$, Yu-Hsien Liao, Shui-Jen Chen \\ Department of Environmental Engineering and Science, National Pingtung University of Science and Technology, \\ Pingtung 91201, Taiwan
}

\begin{abstract}
This research concentrates on the comparison between anode methanol and cathode water liquid-phase polycyclic aromatic hydrocarbons (PAHs) emitted from a single direct methanol fuel cell (DMFC) at different operating parameters (methanol concentration, methanol flowrate, oxygen flowrate, and cell temperature). When the cell was operated at the standard test condition, the concentrations of PAHs in anode methanol and cathode water effluents were from non-detect (ND) to $0.143 \pm 0.111$ and ND to $0.155 \pm 0.052 \mu \mathrm{g} \mathrm{L}^{-1}$, respectively; additionally, those of Total-PAHs were $0.343 \pm 0.310$ and $0.381 \pm 0.093 \mu \mathrm{g} \mathrm{L}^{-1}$, respectively, while those of Total-BaP $\mathrm{eq}_{\text {were }} 19.2 \pm 19.6$ and $160 \pm 54 \mathrm{ng} \mathrm{L}^{-1}$, respectively. Naphthalene was almost the most dominant PAH species when changing one of the operating parameters. For the standard test condition, the anode and cathode emission factor (EF) sums of Total-PAHs and Total-BaP eq $_{\text {were }} 0.06 \pm 0.03 \mu \mathrm{g}$ g-electrode ${ }^{-1}$ and $15.7 \pm 5.00 \mathrm{ng}$ g-electrode ${ }^{-1}$, respectively. The EF sum of Total-PAHs $\left(0.06 \pm 0.03-3.41 \pm 0.86 \mu \mathrm{g}\right.$ g-electrode $\left.{ }^{-1}\right)$ increased when increasing methanol flowrate or concentration and decreasing cell temperature, whereas that of Total-BaP $\mathrm{eq}_{\mathrm{e}}$ $\left(0.91 \pm 0.52-33.2 \pm 5.50 \mathrm{ng}\right.$ g-electrode $\left.{ }^{-1}\right)$ increased with increasing methanol flowrate or decreasing cell temperature and decreased with increasing methanol concentration or decreasing oxygen flowrate.
\end{abstract}

Keywords: Polycyclic aromatic hydrocarbon; Direct methanol fuel cell (DMFC); Emission factor; Liquid-phase PAH.

\section{INTRODUCTION}

For portable power and transportation, polymer electrolyte membrane fuel cells (PEMFCs) are one of the major cell focuses with the key advantages of high energy conversion efficiencies, quick start-up, and zero by-product emissions (Tenson and Baby, 2017); in addition, they provide higher power density and more facile cycling performance than other fuel cell archetypes (Joghee et al., 2015). Among potential long-term solutions, fuel cells based on potentially renewable fuels, such as hydrogen or methanol, has received considerable attention; moreover, the direct methanol fuel cell (DMFC), regarded as the leading direct liquid fuel PEMFC technology, can work at near-room temperature $(\mathrm{Li}$ and Faghri, 2013) and produce electric power directly from high energy density liquid methanol fuel (Joghee et al., 2015).

Like a $\mathrm{H}_{2}-\mathrm{O}_{2}$ PEMFC, a methanol- $\mathrm{O}_{2}$ DMFC has the main components of membrane-electrode assembly (MEA) and bipolar/end plate (Bahrami and Faghri, 2013; Tiwari et

\footnotetext{
* Corresponding author.

Tel.: +886-8-7703202 ext. 7092; Fax: +886-8-7740256

E-mail address: huangkL@mail.npust.edu.tw
}

al., 2013; Falcão et al., 2014). It is common that the MEA consists of five main porous layers: anode gas diffusion layer (GDL), anode catalyst layer, polymer electrolyte membrane (PEM), cathode catalyst layer, and cathode GDL (Bahrami and Faghri, 2013). The binary PtRu alloy, in addition to others (e.g., PtRu, PtOs, PtPd, PtW, PtSn, PtMo, or PtNi), is recognized as an active anode catalyst for DMFCs to enhance methanol oxidation activity and minimize CO poisoning (Tiwari et al., 2013; Mansor et al., 2019); likewise, single-component catalysts (e.g., Pt, Pd, or $\mathrm{Au}$ ) or these single metal coupling with $\mathrm{Co}, \mathrm{Ni}, \mathrm{Cr}$, or $\mathrm{V}$ to form double-component ones can be used in the cathode side (Tiwari et al., 2013). Both anode and cathode catalysts are supported by carbon-based materials, such as functionalized mesoporous carbon, activated carbon nanotube, graphene, and carbon nanosphere) (Tiwari et al., 2013; Mansor et al., 2019), whereas carbon blacks are often used for the fabrication of bipolar/end plates and GDLs (e.g., carbon paper or cloth) (Tran et al., 2015; Zeis, 2015; Lee and Lee, 2016).

According to Joghee et al. (2015), although DMFCs can directly convert the chemical energy stored in liquid methanol fuel to electrical energy, some factors such as lower efficiency and power density as well as higher cost compared to $\mathrm{H}_{2}$-based fuel cells hinder the progress of DMFC commercialization; if first be commercialized, the 
DMFC technology will be favored for small portable power applications. DMFCs are considered as environmentally friendly because they produce lower pollutant emissions, including decreased hydrocarbon emissions as well as decreased levels of $\mathrm{NO}_{\mathrm{x}}, \mathrm{SO}_{2}$, and particulates when compared to gasoline-powered vehicles (Joghee et al., 2015). Nevertheless, they have low emissions of carbon dioxide (a green-house gas) (Li and Faghri, 2013) and some toxic byproducts (e.g., formic acid, methylformate, formaldehyde, and methylal) (Wasmus et al., 1995; Wasmus and Küver, 1999). More fundamental research must be conducted to make DMFC technology more appealing and the DMFC systems more competitive in the portable power market $(\mathrm{Li}$ and Faghri, 2013).

Although $\mathrm{H}_{2}-\mathrm{O}_{2}$ PEMFCs are claimed to produce electric energy with zero emission, the emissions of polycyclic aromatic hydrocarbons (PAHs) from a $\mathrm{H}_{2}-\mathrm{O}_{2}$ PEMFC associated with the uses of carbon materials were addressed in our earlier works (Huang et al., 2015, 2016, 2018). PAHs, present in different phases (liquid, solid, and gas), have long been concerned for their adverse impacts on health and the environment (Fan et al., 2017; Lai et al., 2017; Li et al., 2017; Saha et al., 2017; Wang et al., 2017; Jiang et al., 2018; Horák et al., 2018). PAHs, generated from sources, are now widely distributed in the global atmosphere, particularly in that of populated and industrial regions (Fan et al., 2017; Lai et al., 2017; Li et al., 2017; Saha et al., 2017; Dat et al., 2018; Li et al., 2018; Wright et al., 2018; $\mathrm{Xu}$ et al., 2018; Zhang et al., 2018). The formation of PAHs in natural and anthropogenic processes is principally due to the incomplete combustion of carbonaceous material through pyrolysis and pyrosynthesis processes, which involve in complicated mechanisms such as the formation of the "first aromatic ring", the hydrogen abstraction and acetylene $\left(\mathrm{C}_{2} \mathrm{H}_{2}\right)$ addition along with ring growth, DielsAlder mechanism, phenyl-addition-cyclization, methyl addition/cyclization, and more (Richter and Howard, 2000; Cheruiyot et al., 2015; Reizer et al., 2019).

To the best of our knowledge, the emission of PAHs from DMFCs has not been reported presently. In this study, we explored the emissions anode versus cathode liquidphase PAHs and BaPeq from a DMFC under different anode methanol and cathode oxygen flowrates, methanol concentrations, and temperatures. The liquid-phase PAHs emitted on the cathode are originally present in water vapor which can be naturally condensed to water after emission. On the anode side, the PAHs may vaporize with methanol solution and then are present in the air. Therefore, the liquid-phase PAHs in anode and cathode effluents generated during DMFC operation may increase the anthropogenic liquid or gas aerosols containing PAHs with adverse effects on air quality and health.

\section{MATERIALS AND METHODS}

\section{Membrane-Electrode Assembly (MEA) and Fuel Cell Emission Test}

In this study, the tested membrane-electrode assemblies (MEAs) were all purchased from Hephas Energy Co., Ltd.
Each MEA, consisted of a proton exchange membrane (solid electrolyte) (Nafion-115) sandwiched with two dispersed catalyst layers and gas diffusion layers (GDLs), had an anode PtRu loading of $3 \mathrm{mg} \mathrm{cm}{ }^{-2}$ and a cathode Pt loading of $0.3 \mathrm{mg} \mathrm{cm}^{-2}$. The structure of MEA was reported in our earlier papers (Huang et al., 2006; Lai et al., 2012; Huang et al., 2015, 2016, 2018).

The DMFC used in PAH emission tests had an MEA symmetrically sandwiched by Telfon gaskets, carbon (graphite) blocks (with gas flow channel), and copper current collectors. The single cell was installed on a standard fuel cell test station that worked at $80^{\circ} \mathrm{C}$ or $60^{\circ} \mathrm{C}\left(40^{\circ} \mathrm{C}\right.$ for the cathode humidifier) and $0.3 \mathrm{~V}$ for $6.4 \mathrm{~h}$ conditioning and then another $6.4 \mathrm{~h}$ for $\mathrm{PAH}$ collection under different anode methanol and cathode oxygen flow rates (2-10 and 100-150 $\mathrm{mL} \mathrm{min}^{-1}$, respectively). The anode methanol concentration of $4 \mathrm{M}$ was also tested in comparison to $2 \mathrm{M}$. Table 1 summarizes the tested different operating conditions. The operating condition of $\mathrm{A}$ in this table is denoted as the standard test condition (methanol concentration $=2 \mathrm{M}$, methanol flowrate $=2 \mathrm{~mL} \mathrm{~min}^{-1}$, oxygen flowrate $=$ $150 \mathrm{~mL} \mathrm{~min}^{-1}$, and cell temperature $=80^{\circ} \mathrm{C}$ ).

\section{PAH Sampling, Analysis, and Quality Control}

During PAHs sampling, the methanol (fuel) was circulated using a peristaltic pump (ChromTech TP-320) between the anode and a fuel reservoir, while the cathode was fed with oxygen regulated by a mass flow controller (Fig. 1). The PAH sampling system, connected to the DMFC, simultaneously collected PAHs from the anode and cathode emission ports. For each sampling, the anode sample was taken from the methanol, whereas a glass water collector was used to collect the cathode effluent containing water-phase PAHs. Similar cathode sampling systems for PAH collection were also addressed in our previous works (Huang et al., 2015, 2016, 2018).

Triplicate PAH samplings $(n=3)$ were conducted in each experiment. We measured 21 PAHs: naphthalene (Nap), acenaphthylene (AcPy), acenaphthene (Acp), fluorene (Flu), phenanthrene (PA), anthracene (Ant), fluoranthene (FL), pyrene (Pyr), benzo(a)anthracene (BaA), chrysene (CHR), cyclopenta(c,d)pyrene (CYC), benzo(b)fluoranthene (BbF), benzo(k)fluoranthene $(\mathrm{BkF})$, benzo(e)pyrene (BeP), benzo(a)pyrene (BaP), perylene (PER), indeno(1,2,3,cd)pyrene (IND), dibenzo(a,h)anthrance (DBA), benzo(b)chrycene $(\mathrm{BbC})$, benzo(ghi)perylene (BghiP), and coronene (COR). The $21 \mathrm{PAH}$ species were classified into three categories: low molecular weight (LMW-PAHs, 2-/3ring PAHs: NaP, AcPy, AcP, Flu, Ant, and PA), middle molecular weight (MMW-PAHs, 4-ring PAHs: FL, Pyr, $\mathrm{BaA}$, and CHR), and high molecular weight (HMW-PAHs, 5-/6-/7-ring PAHs: CYC, BbF, BkF, BeP, BaP, PER, DBA, $\mathrm{BbC}$, IND, BghiP, and COR). The Total-PAHs concentration was obtained from the sum of the concentrations of 21 PAH species.

It can be checked elsewhere for the details of PAHs extraction by Soxhlet extraction method, the identification/ quantification of PAHs (with blank correction) by gas chromatograph/mass spectrometry (GC/MS), and the quality 
Table 1. Operating conditions (OPs: methanol concentration, methanol flowrate, $\mathrm{O}_{2}$ flowrate, and cell temperature) and emission factors (EFs) of water-phase Total-PAHs and Total-BaP $\mathrm{eq}_{\text {for the }}$ anodes $(\mathrm{a})$, cathodes $(\mathrm{c})$, and sums $(\mathrm{a}+\mathrm{c})$ at these conditions.

\begin{tabular}{lllll}
\hline OPs & Methanol concentration, $\mathrm{M}$ & Methanol flowrate, $\mathrm{mL} \mathrm{min}$ & $\mathrm{O}_{2}$ flowrate, $\mathrm{mL} \mathrm{min}^{-1}$ & Cell temperature, ${ }^{\circ} \mathrm{C}$ \\
\hline $\mathrm{A}$ & 2 & 2 & 150 & 80 \\
$\mathrm{~B}$ & 2 & 10 & 150 & 80 \\
$\mathrm{C}$ & 4 & 2 & 150 & 80 \\
$\mathrm{D}$ & 2 & 2 & 100 & 80 \\
$\mathrm{E}$ & 2 & 2 & 150 & 60 \\
\hline
\end{tabular}

\begin{tabular}{|c|c|c|c|c|c|c|}
\hline \multirow{2}{*}{ EFs } & \multicolumn{3}{|c|}{ Total-PAHs $\left(\mu \mathrm{g}\right.$ g-electrode $\left.{ }^{-1}\right)$} & \multicolumn{3}{|c|}{ Total-BaP $_{\text {eq }}\left(\right.$ ng g-electrode $\left.{ }^{-1}\right)$} \\
\hline & $\mathrm{a}$ & $\mathrm{c}$ & Sum & $\mathrm{a}$ & $\mathrm{c}$ & Sum \\
\hline $\mathrm{A}$ & $0.03 \pm 0.03$ & $0.03 \pm 0.01$ & $0.06 \pm 0.03$ & $1.61 \pm 1.65$ & $14.1 \pm 4.72$ & $15.7 \pm 5.00$ \\
\hline B & $1.46 \pm 0.23$ & $1.96 \pm 0.83$ & $3.41 \pm 0.86$ & $26.0 \pm 11.3$ & $2.74 \pm 1.42$ & $28.7 \pm 11.4$ \\
\hline $\mathrm{C}$ & $1.79 \pm 0.50$ & $1.50 \pm 0.90$ & $3.29 \pm 1.03$ & $5.62 \pm 1.74$ & $2.41 \pm 0.92$ & $8.03 \pm 1.97$ \\
\hline $\mathrm{D}$ & $0.06 \pm 0.03$ & $0.01 \pm 0.00$ & $0.07 \pm 0.03$ & $0.90 \pm 0.52$ & $0.01 \pm 0.00$ & $0.91 \pm 0.52$ \\
\hline $\mathrm{E}$ & $1.97 \pm 1.19$ & $0.90 \pm 0.60$ & $2.87 \pm 1.34$ & $13.4 \pm 4.02$ & $19.8 \pm 3.75$ & $33.2 \pm 5.50$ \\
\hline
\end{tabular}

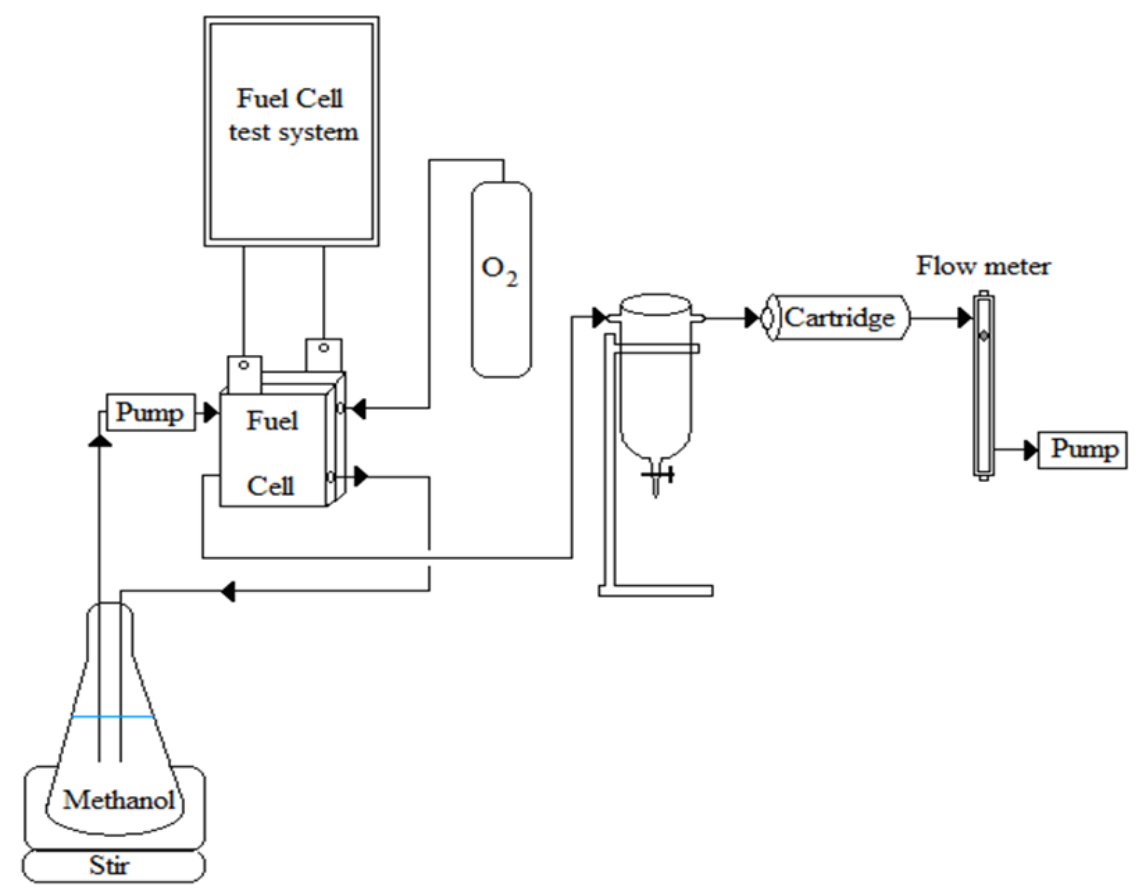

Fig. 1. The scheme of single PEMFC for PAH emission tests.

assurance (QA)/quality control (QC) procedures for PAHs GC/MS analysis (Huang et al., 2015). The correlation coefficients of the calibration curves were 0.994-0.999. Ten consecutive injections of a PAH 610-M standard yielded an average relative standard deviation (RSD) of the GC/MS integration area of $3.0 \%$ with a range of $0.8-$ $5.1 \%$. The total recovery efficiencies of PAHs from seven consecutive injections ranged from $83 \%$ to $112 \%$, while the average recoveries of the five internal standards were $85-93 \%$ across seven consecutive injections.

The coefficients of variation for repeat injections of the standard solution (containing PAH Mixture-610 M [16 PAHs] and five Merck PAH standards) were all less than $5 \%$ for all of the analyzed PAHs, whereas those obtained by replicate analysis were $2-10 \%$. Analyses of serial dilutions of PAH standards revealed the limits of detection (LODs) of GC/MS to be between 0.071 and $0.936 \mathrm{ng}$ for the 21 PAH compounds. The limit of quantification (LOQ) was defined as the LOD divided by the sampling volume. The LOQ values of the $21 \mathrm{PAH}$ compounds for cell effluent and emission gas were $0.102-2.470 \mathrm{ng} \mathrm{L}^{-1}$ and $0.076-0.175 \mathrm{ng} \mathrm{Nm}^{-3}$, respectively.

\section{RESULTS AND DISCUSSION}

Effect of Methanol Flowrate on Anode versus Cathode Liquid-phase PAHs and BaP eq Emissions

For the tests of PEMFC PAH emissions at different flowrates, the anode methanol and cathode oxygen flowrates meet the stoichiometric requirements for the anode and 
cathode feeding gases, respectively (Joghee et al., 2015; Huang et al., 2016). Fig. 2 shows the concentration profiles of liquid-phase 21 PAHs collected from the anode methanol solution and cathode effluent of DMFC operated at $80^{\circ} \mathrm{C}$ and different anode methanol flowrates $\left(2\right.$ and $\left.10 \mathrm{~mL} \mathrm{~min}^{-1}\right)$. At anode methanol flowrate of $2 \mathrm{~mL} \min ^{-1}$, only 5 and 6 of 21-PAH species were detected in the anode and cathode effluents: additionally, $\mathrm{BaP}, \mathrm{PER}, \mathrm{BbC}$, and $\mathrm{COR}$ were observed in both effluents. Moreover, the concentrations of PAHs in circulated $2 \mathrm{M}$ methanol solution and cathode effluent ranged from non-detect (ND) (21-PAH except Ant, $\mathrm{BaP}, \mathrm{PER}, \mathrm{BbC}$, and $\mathrm{COR}$ ) to $0.143 \pm 0.111$ (COR) (Fig. 2(a)) and ND (21-PAH except BaP, CHR, PER, DBA, $\mathrm{BbC}$, and COR) to $0.155 \pm 0.052$ (DBA) (Fig. 2(b)) $\mu \mathrm{g} \mathrm{L}^{-1}$, respectively. The same PAH species detected on anode and cathode sides had similar concentrations, except $\mathrm{BaP}$ and PER; furthermore, their 21-PAH concentration profiles were also similar, regardless of the difference in aqueous solutions.

When the anode methanol flowrate was raised to $10 \mathrm{~mL} \mathrm{~min}^{-1}$, the 21-PAH concentration profiles were again similar on the anode and cathode sides, but they were significantly different from those at $2 \mathrm{~mL} \mathrm{~min}^{-1}$. The concentrations of PAHs in methanol solution and cathode effluent were from ND (Acp, Ant, Pyr, BaA, BbF, BkF, $\mathrm{BeP}$, and BghiP) to $8.18 \pm 1.84$ (NaP) (Fig. 2(a)) and ND (Ant, Pyr, BaA, BbF, BkF, BeP, BaP, and BghiP) to $13.9 \pm$ 7.00 (NaP) (Fig. 2(b)) $\mu \mathrm{g} \mathrm{L}^{-1}$, respectively. At the greater methanol flowrate, some LMW- and MMW-PAH species could be observed, and among them, $\mathrm{NaP}$ exhibited concentrations than the others; most of these individual LMW- and MMW-PAH species had significantly higher concentrations than the PAH species detected at $2 \mathrm{~mL} \mathrm{~min}^{-1}$. This phenomenon is mainly attributed to the fact that fluid convention was greater at the higher flowrate, resulting in the more release or desorption of PAHs from carbon materials into the anode methanol, although the $\pi-\pi$ interaction was possibly strong between PAHs and the graphitic structure of carbon materials (Kah et al., 2011). Additionally, it is known that each of the 21 PAHs has low water solubility, and the water solubility of PAHs approximately decreases with the increase of aromatic ring number (e.g., water solubility of Nap, Pyr, and $\mathrm{BaP}$ at $25^{\circ} \mathrm{C}=31.0,0.132$, and $0.0038 \mathrm{mg} \mathrm{L}^{-1}$, respectively (ENVIRO Wiki, 2017)). However, the fluid pumped into the cathode was oxygen gas, not methanol and the principle effluent of cathode was water, so it is interesting to find that the 21-PAH concentration profiles were similar on the anode and cathode sides, revealing that the probable presence of methanol crossover (i.e., the movement of unreacted methanol from anode to cathode through the membrane (Kim et al., 2017)).

At methanol flowrate of $2 \mathrm{~mL} \mathrm{~min}^{-1}$ (standard test condition), the concentrations of LMW-, MMW-, and HMW-PAHs in effluents were $0.065 \pm 0.112$, ND, and $0.278 \pm 0.201 \mu \mathrm{g} \mathrm{L}^{-1}$, respectively for anode and $14.2 \pm$ $1.5,1.20 \pm 0.26$, and $1.43 \pm 0.52 \mu \mathrm{g} \mathrm{L}^{-1}$, respectively for cathode (Fig. 3(a)). Therefore, the anode and cathode effluents had similar Total-PAHs concentrations $(0.343 \pm$ 0.310 and $0.381 \pm 0.093 \mu \mathrm{g} \mathrm{L}^{-1}$, respectively), while the Total-BaP ${ }_{\text {eq }}$ concentration of the former $\left(19.2 \pm 19.6 \mathrm{ng} \mathrm{L}^{-1}\right)$ was roughly one-eighth that of the latter $\left(160 \pm 54 \mathrm{ng} \mathrm{L}^{-1}\right)$, because the anode effluent had higher concentrations of PAHs with greater toxic equivalence factors (TEFs). In this study, the benzo(a)pyrene (BaP)-equivalent carcinogenic potency $\left(\mathrm{BaP}_{\mathrm{eq}}\right)$ of a PAH species was calculated using the product of its toxic equivalence factor (TEF) and concentration (Nisbet and LaGoy, 1992). For the same reason, the Total-BaP ${ }_{\text {eq }}$ concentration of anode effluent $(865 \pm$ $377 \mathrm{ng} \mathrm{L}^{-1}$ ) was greater than that of cathode effluent (91.4 $\pm 47.3 \mathrm{ng} \mathrm{L}{ }^{-1}$ ) at methanol flowrate of $10 \mathrm{~mL} \mathrm{~min}^{-1}$ (Fig. 3(b)). The corresponding concentrations of LMW-, MMW-, HMW-, and Total-PAHs were $14.1 \pm 1.5,1.20 \pm$ $0.26,1.43 \pm 0.53$, and $16.8 \pm 1.6 \mu \mathrm{g} \mathrm{L}^{-1}$, respectively in anode effluent and $20.9 \pm 9.4,1.30 \pm 0.47,0.59 \pm 0.16$, and $22.7 \pm 9.9 \mu \mathrm{g} \mathrm{L}{ }^{-1}$, respectively in cathode effluent.

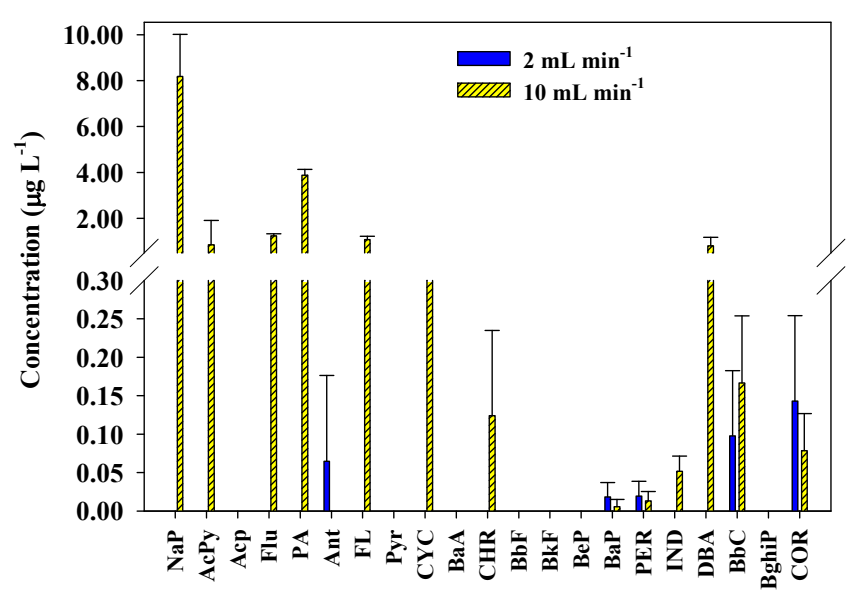

(a)

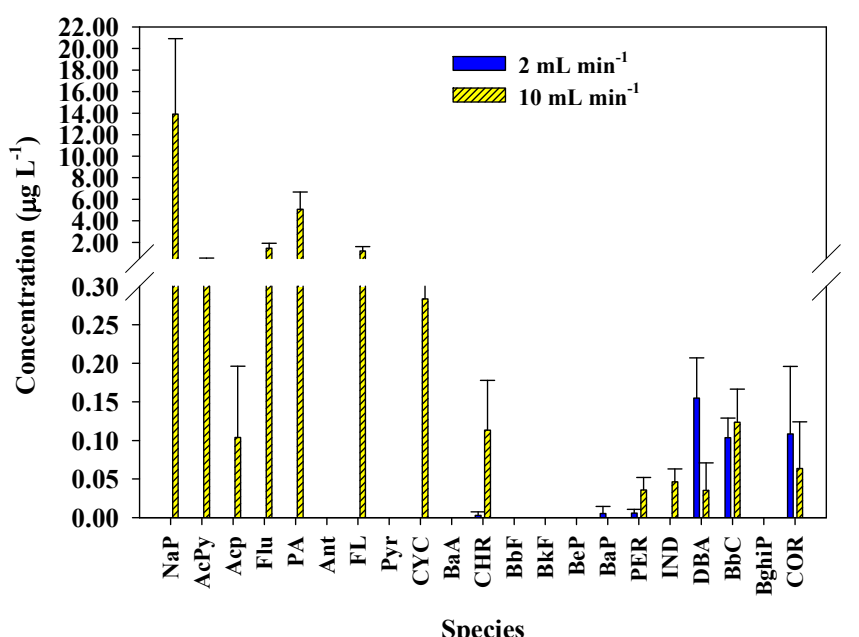

(b)

Fig. 2. Characteristic profiles of (a) anode and (b) cathode water-phase PAHs emitted from the DMFC at different methanol flowrates $\left(2\right.$ and $\left.10 \mathrm{~mL} \mathrm{~min}^{-1}\right)\left(\right.$ methanol concentration $=2 \mathrm{M}, \mathrm{O}_{2}$ flowrate $=150 \mathrm{~mL} \mathrm{~min}^{-1}$, and cell temperature $\left.=80^{\circ} \mathrm{C}\right)(\mathrm{n}=3)$. 


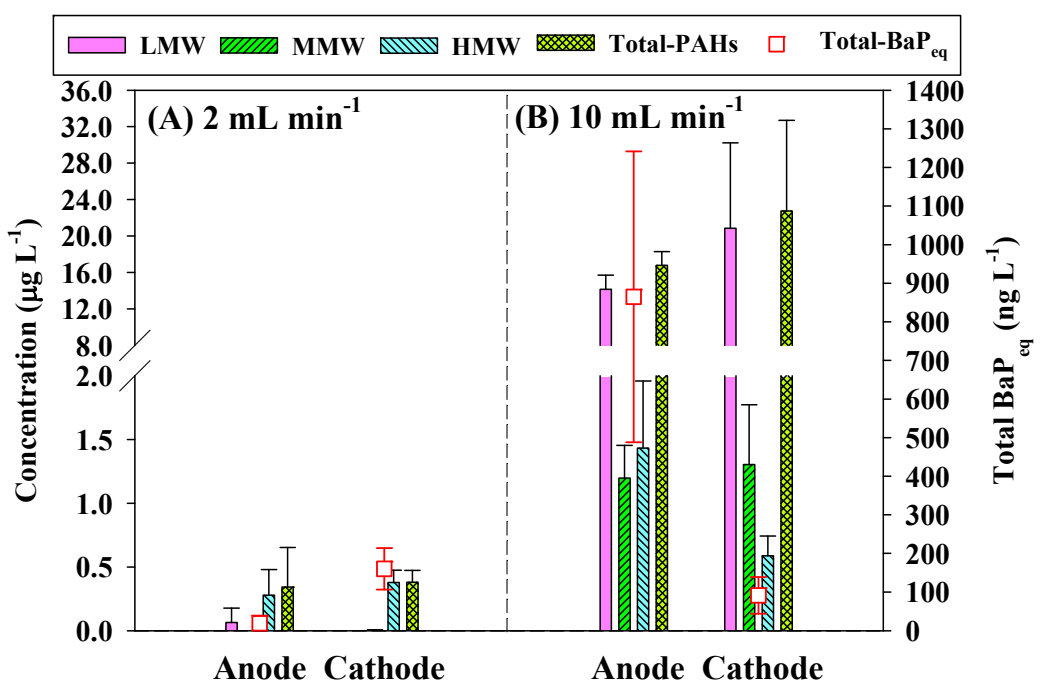

Fig. 3. Concentrations of water-phase LMW-, MMW-, HMW-, and Total-PAHs and Total-BaP ${ }_{\text {eq }}$ of anode and cathode at different methanol flowrates ((a) 2 and (b) $\left.10 \mathrm{~mL} \mathrm{~min}^{-1}\right)(\mathrm{n}=3)$.

\section{Effect of Methanol Concentration on Anode versus Cathode Liquid-phase PAHs and BaP eq Emissions}

The methanol concentrations used for active and passive DMFCs are commonly 1-2 M (3-6 wt \%) and $\sim 3 \mathrm{M}$ (10 wt\%), respectively (Li and Faghri, 2013). The DMFC adopted in this study was an active one, so the methanol concentration of $2 \mathrm{M}$ was tested, while a higher methanol concentration (4 M) was also tested for comparison. For using $4 \mathrm{M}$ methanol as the anode fuel at $2 \mathrm{~mL} \mathrm{~min}^{-1}$, anode and cathode effluents exhibited similar 21-PAH concentration profiles (Figs. 4(a) and 4(b)), which were significantly different from those using methanol concentration of $2 \mathrm{M}$ at $2 \mathrm{~mL} \mathrm{~min}^{-1}$, but similar to those using methanol

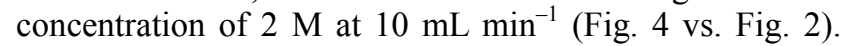
The concentrations of PAHs in anode and cathode effluents ranged from $\mathrm{ND}$ (Ant, $\mathrm{Pyr}, \mathrm{BaA}, \mathrm{BbF}, \mathrm{BkF}, \mathrm{BeP}, \mathrm{BaP}$, and BghiP) to $11.1 \pm 3.6(\mathrm{NaP})$ (Fig. 4(a)) and ND (DBA plus those for anode) to $9.80 \pm 7.38(\mathrm{NaP})$ (Fig. 4(b)) $\mu \mathrm{g} \mathrm{L}^{-1}$, respectively. Of all these $\mathrm{PAH}$ species, $\mathrm{NaP}$ exhibited the highest concentration. Moreover, NaP, AcPy, Acp, Flu, PA, FL, CYC, and CHR, which were not detected at methanol concentration of $2 \mathrm{M}$, could be observed with significantly higher concentrations than the other PAH species. Nevertheless, the concentrations of PER, IND, BbC, and COR at both methanol concentrations did not follow this trend in anode or cathode effluent. Accordingly, it is reasonable to infer that the mentioned LMW- or MMWPAHs were more soluble in the methanol solution with the higher concentration (4 M). In fact, the cell energy density can be increased at greater methanol concentration; on the other hand, methanol crossover becomes more severe to reduce the cell voltage and decreases the fuel efficiency because mixed potential develops at the cathode, and deterioration of fuel utilization occurs at the anode ( $\mathrm{Li}$ and Faghri, 2013; Tiwari et al., 2013).

The main electrochemical reactions at anode and cathode in an acid-based DMFC are methanol oxidation (reaction 1) and oxygen reduction (reaction 2), respectively
(Tiwari et al., 2013).

$$
\mathrm{CH}_{3} \mathrm{OH}+\mathrm{H}_{2} \mathrm{O} \rightarrow \mathrm{CO}_{2}+6 \mathrm{H}^{+}+6 \mathrm{e}^{-} \quad \mathrm{E}^{0}=0.016 \mathrm{~V} / \mathrm{SHE}
$$

for which the standard hydrogen electrode (SHE) is used as a reference electrode.

$$
1.5 \mathrm{O}_{2}+6 \mathrm{H}^{+}+6 \mathrm{e}^{-} \rightarrow 3 \mathrm{H}_{2} \mathrm{O} \quad \mathrm{E}^{0}=1.229 \mathrm{~V} / \mathrm{SHE}
$$

The overall reaction process can be shown below:

$$
\mathrm{CH}_{3} \mathrm{OH}+1.5 \mathrm{O}_{2} \rightarrow \mathrm{CO}_{2}+2 \mathrm{H}_{2} \mathrm{O} \quad \mathrm{E}^{0}=1.21 \mathrm{~V} / \mathrm{SHE}
$$

$\mathrm{CO}_{2}$ will be generated from the methanol oxidation at anode during the operation of DMFC based on reaction 1 . This situation might cause the $\mathrm{CO}_{2}$ crossover, driven by the gas pressure gradient between the anode and the cathode of the MEA, through the Nafion membrane in the DMFC even fed with $2 \mathrm{M}$ methanol solution (Jiang and $\mathrm{Chu}, 2002)$. When the DMFC was fed with $4 \mathrm{M}$ methanol, the $\mathrm{CO}_{2}$ release from the anode should be more difficult, due to the significant increase of mass transport resistance at the anode in order to alleviate the methanol crossover; as a result, more $\mathrm{CO}_{2}$ might crossover through the electrolyte membrane and escaped to the ambient from the cathode (Jiang and Chu, 2002; Li and Faghri, 2013).

For easy comparison of tested results, the data of Fig. 3(a) for the anode fed by $2 \mathrm{M}$ methanol (standard test condition) are also shown in Fig. 5(a). When the anode was fed by $4 \mathrm{M}$ methanol solution at $2 \mathrm{~mL} \mathrm{~min}^{-1}$, the concentrations of LMW-, MMW-, HMW-, and Total-PAHs in effluents were $18.3 \pm 4.6,1.43 \pm 0.32,0.37 \pm 0.11$, and $20.1 \pm 5.0 \mu \mathrm{g} \mathrm{L}^{-1}$, respectively for anode and $15.7 \pm 9.8,0.91$ $\pm 0.19,0.22 \pm 0.03$, and $16.9 \pm 9.9 \mu \mathrm{g} \mathrm{L}^{-1}$, respectively for cathode (Fig. 5(b)). Therefore, the concentrations of 


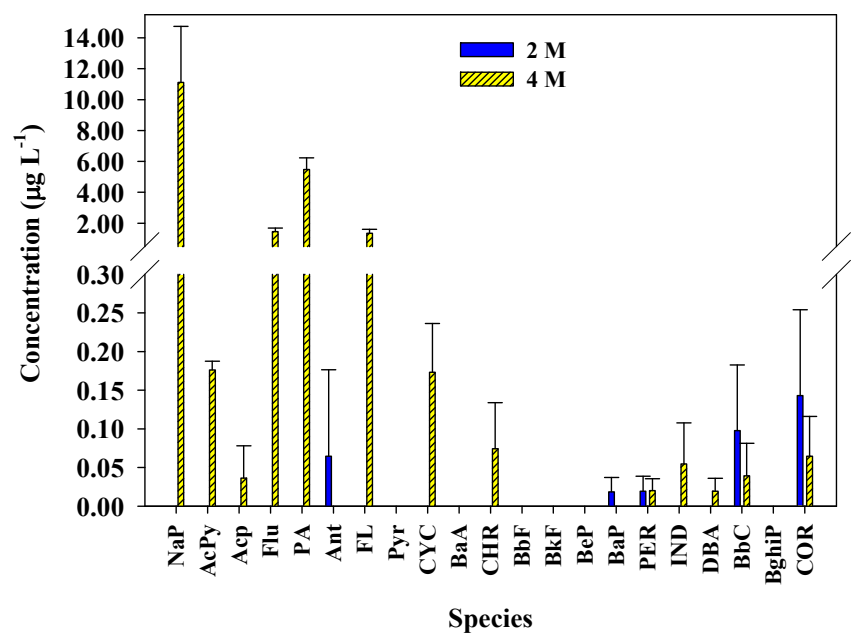

(a)

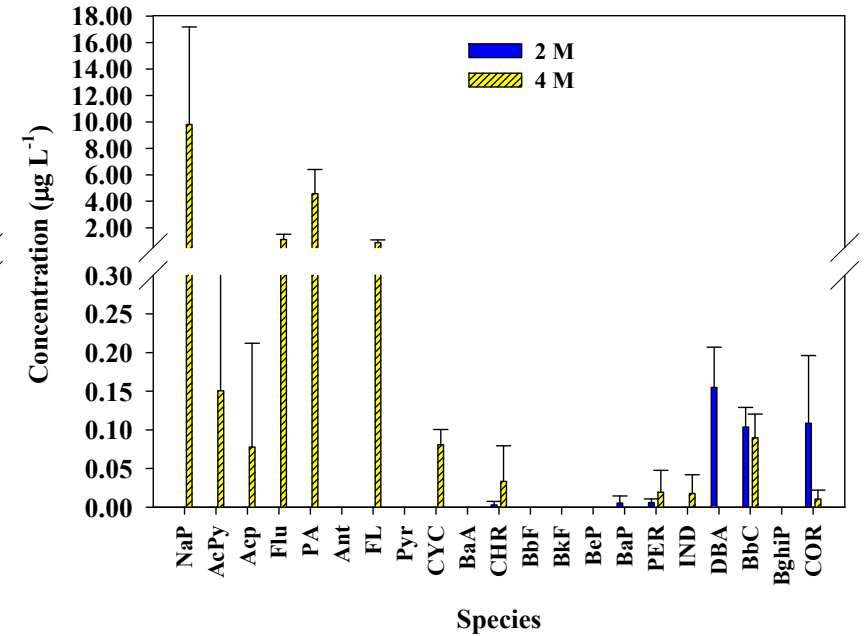

(b)

Fig. 4. Characteristic profiles of (a) anode and (b) cathode water-phase PAHs emitted from the DMFC at different methanol concentrations $(2$ and $4 \mathrm{M})$ (methanol flowrate $=2 \mathrm{~mL} \mathrm{~min}^{-1}, \mathrm{O}_{2}$ flowrate $=150 \mathrm{~mL} \mathrm{~min}^{-1}$, and cell temperature $\left.=80^{\circ} \mathrm{C}\right)(\mathrm{n}=3)$.

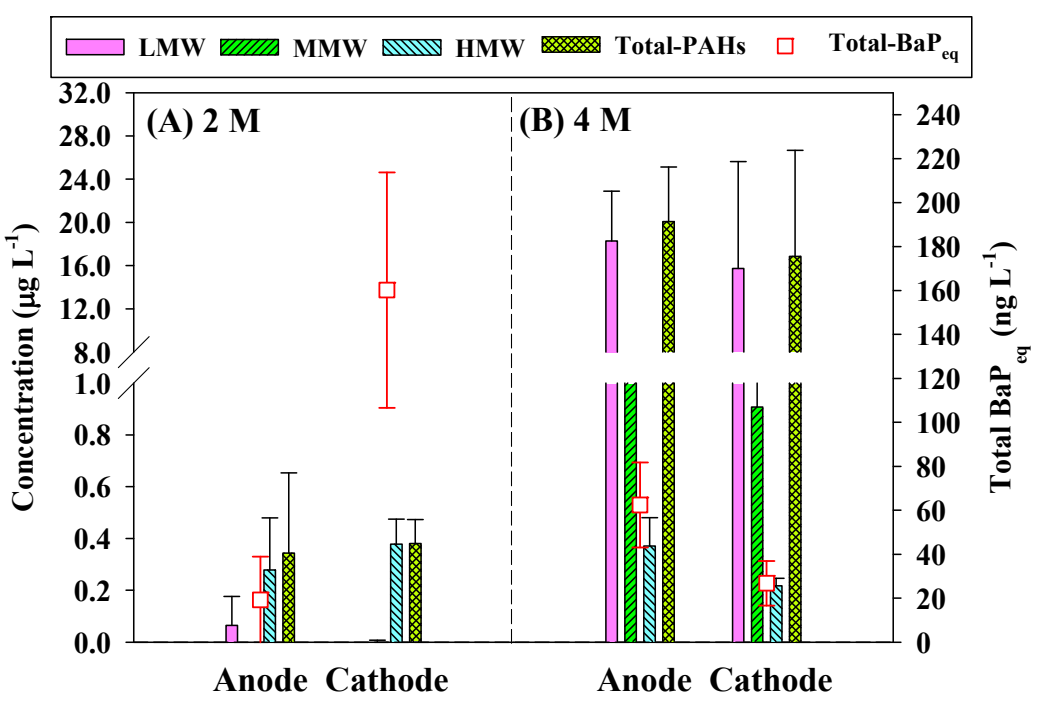

Fig. 5. Concentrations of water-phase LMW-, MMW-, HMW-, and Total-PAHs and Total-BaP eq anode and cathode at different methanol concentrations ((a) 2 and (b) 4 M) $(n=3)$.

molecular weight classified PAHs of anode and cathode effluents followed the order LMW- > MMW- > HMWPAHs, while the Total-PAHs concentration was greater in anode effluent than in cathode one. Similarly, the corresponding Total- $\mathrm{BaP}_{\mathrm{eq}}$ concentration of the former $\left(62.4 \pm 19.3 \mathrm{ng} \mathrm{L}^{-1}\right)$ was greater than that of the latter $(26.8$ $\left.\pm 10.2 \mathrm{ng} \mathrm{L}^{-1}\right)$. These two Total-BaP $\mathrm{eq}_{\text {c }}$ concentrations in $4 \mathrm{M}$ methanol effluent were higher than that of anode effluent but lower than that of cathode effluent in $2 \mathrm{M}$ methanol chiefly because of the difference in PAH species concentration along with corresponding TEF.

\section{Effect of $\mathrm{O}_{2}$ Flowrate on Anode versus Cathode Liquid- phase PAHs and $\mathrm{BaP}_{\text {eq }}$ Emissions}

At the cathode oxygen flowrate of $100 \mathrm{~mL} \mathrm{~min}^{-1}$, the concentrations of individual PAHs in anode and cathode effluents ranged from ND (21-PAH except AcPy, FL, CYC, CHR, BaP, BbC, and COR) to $0.200 \pm 0.025$ (FL) (Fig. 6(a)) and ND (21-PAH except AcPy, BbC, and COR) to $0.098 \pm 0.138$ (NaP) (Fig. 6(b)) $\mu \mathrm{g} \mathrm{L}^{-1}$, respectively. In comparison to the cathode fed using oxygen at $150 \mathrm{~mL} \mathrm{~min}^{-1}$, more PAH species were detected on the anode side (Fig. 6(a)), but an opposite trend was observed on the cathode side (Fig. 6(b)) when the cathode oxygen flowrate was $100 \mathrm{~mL} \mathrm{~min}^{-1}$.

The data of Fig. 3(a) for the cathode operated at the oxygen flowrate of $150 \mathrm{~mL} \mathrm{~min}{ }^{-1}$ (standard test condition) are also shown in Fig. 7(a) for the sake of easy comparison. When the cathode was fed by oxygen flowrate of 100 $\mathrm{mL} \mathrm{min}^{-1}$, the concentrations of LMW-, MMW-, HMW-, and Total-PAHs were $0.155 \pm 0.072,0.285 \pm 0.145,0.361$ \pm 0.163 , and $0.800 \pm 0.236 \mu \mathrm{g} \mathrm{L} \mathrm{L}^{-1}$, respectively in anode 


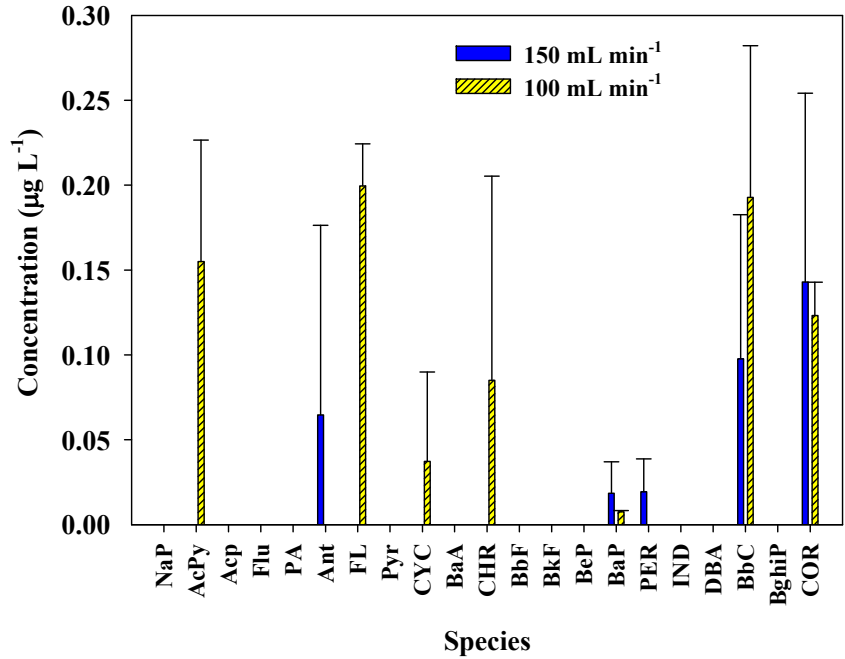

(a)

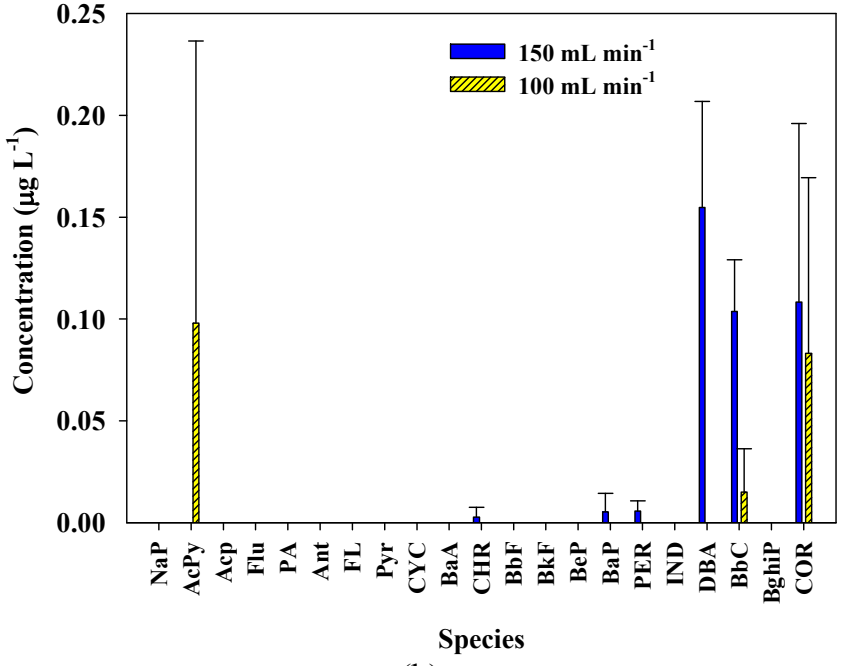

(b)

Fig. 6. Characteristic profiles of (A) anode and (B) cathode water-phase PAHs emitted from the DMFC at different $\mathrm{O}_{2}$ flowrates $\left(100\right.$ and $\left.150 \mathrm{~mL} \mathrm{~min}^{-1}\right)\left(\right.$ methanol flowrate $=2 \mathrm{~mL} \mathrm{~min}^{-1}$, methanol concentration $=2 \mathrm{M}$, and cell temperature $=$ $\left.80^{\circ} \mathrm{C}\right)(\mathrm{n}=3)$.

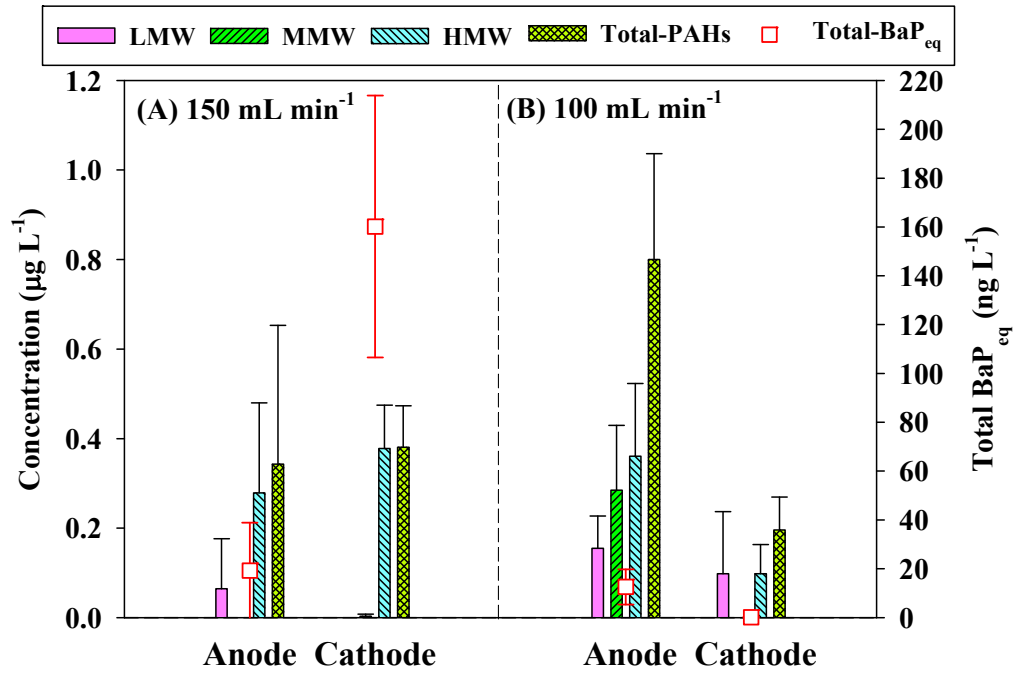

Fig. 7. Concentrations of water-phase LMW-, MMW-, HMW-, and Total-PAHs and Total-BaP $\mathrm{eq}_{\text {of }}$ anode and cathode at different $\mathrm{O}_{2}$ flowrates ((A) 150 and (B) $\left.100 \mathrm{~mL} \mathrm{~min}^{-1}\right)(\mathrm{n}=3)$.

effluent and $0.098 \pm 0.139, \mathrm{ND}, 0.098 \pm 0.065$, and 0.196 $\pm 0.073 \mu \mathrm{g} \mathrm{L}^{-1}$, respectively in cathode effluent (Fig. 7(b)). Hence, the corresponding Total- $\mathrm{BaP}_{\mathrm{eq}}$ concentration in anode effluent $\left(12.5 \pm 7.2 \mathrm{ng} \mathrm{L}{ }^{-1}\right)$ was greater than that in cathode one $\left(0.181 \pm 0.052 \mathrm{ng} \mathrm{L}^{-1}\right)$. However, these two

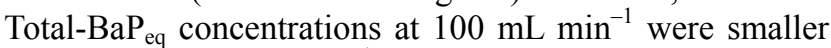
than those at $150 \mathrm{~mL} \mathrm{~min}^{-1}$. Obviously, lowering the cathode oxygen flowrate decreased the Total-PAHs and Total- $\mathrm{BaP}_{\mathrm{eq}}$ emissions in cathode effluent. This finding should be related to the partitioning of individual PAH species between gas and water phases (Lee et al., 2004).

\section{Effect of Cell Temperature on Anode versus Cathode Liquid-phase PAHs and BaP eq Emissions}

The cell temperatures of $60^{\circ} \mathrm{C}$ and $80^{\circ} \mathrm{C}$ were tested in this study, because the temperature range of $60-120^{\circ} \mathrm{C}$ is usually used in DMFC tests (Li and Faghri, 2013; Joghee et al., 2015). Figs. 8(a) and 8(b) shows the concentration profiles of 21 individual PAHs in anode and cathode effluents, respectively at $60^{\circ} \mathrm{C}$. More $\mathrm{PAH}$ species were observed in the two effluents. For the cell operated at the temperature of $60^{\circ} \mathrm{C}$, the concentrations of individual PAHs in anode and cathode effluents ranged from ND (Ant, Pyr, BaA, BbF, BkF, BeP, BaP, and BghiP) to $52.9 \pm$ $33.4(\mathrm{NaP})$ (Fig. 8(a)) and ND (the same as those for anode) to $18.5 \pm 2.2(\mathrm{NaP})$ (Fig. $8(\mathrm{~b})) \mu \mathrm{g} \mathrm{L}^{-1}$, respectively. Notably, more PAH species were detected in both of the effluents at $60^{\circ} \mathrm{C}$, in comparison to the cell operation at $80^{\circ} \mathrm{C}$. For the same $\mathrm{PAH}$ species, its concentration was also greater at the lower temperature, consistent with the fact that the water solubility of a PAH species was lower when the temperature is higher. This result is similar to the 
observation that the water-phase $\mathrm{PAH}$ concentrations were greater at $65^{\circ} \mathrm{C}$ than at $90^{\circ} \mathrm{C}$ for a $\mathrm{H}_{2}-\mathrm{O}_{2}$ PEMFC in our earlier work (Huang et al., 2018).

For comparison, the data of Fig. 3(a) for the cell operated at $80^{\circ} \mathrm{C}$ (standard test condition) are also shown in Fig. 9(a). When the cell operated at $60^{\circ} \mathrm{C}$, methanol solution $=2 \mathrm{M}$, methanol flowrate $=2 \mathrm{~mL} \min ^{-1}$, and oxygen flowrate $=$ $150 \mathrm{~mL} \mathrm{~min}^{-1}$, the concentrations of LMW-, MMW-, HMW-, and Total-PAHs were 82.2 $\pm 50.7,5.68 \pm 3.77$, $2.66 \pm 0.50$, and $90.5 \pm 54.8 \mu \mathrm{g} \mathrm{L}^{-1}$, respectively in anode effluent and $31.2 \pm 18.8,3.96 \pm 2.54,3.26 \pm 0.84$, and 44.3 $\pm 22.2 \mu \mathrm{g} \mathrm{L}^{-1}$, respectively in cathode effluent (Fig. 9(b)). Therefore, the concentrations of molecular weight classified PAHs of anode and cathode effluents were in the order LMW- > MMW- > HMW-PAHs. Although the Total-PAHs concentration was greater in anode effluent than in cathode

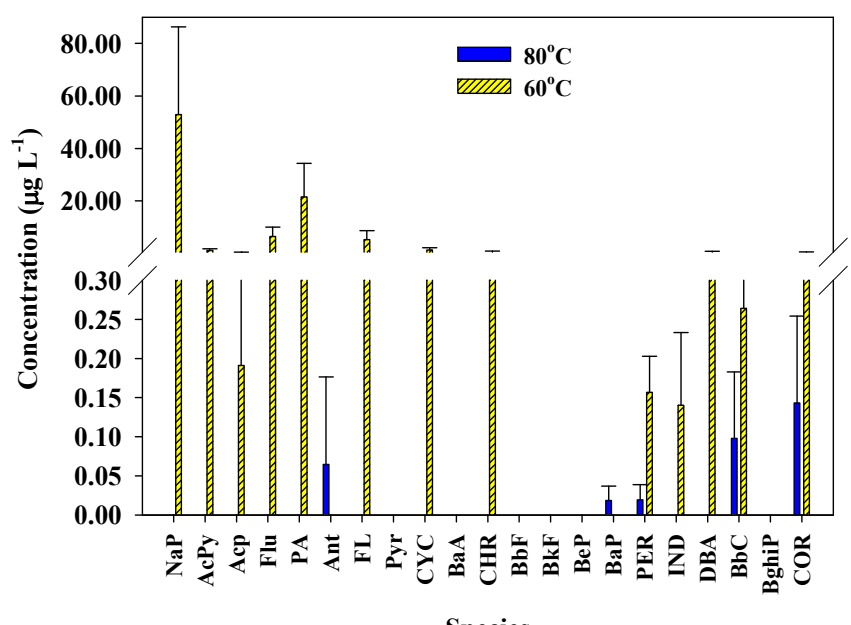

(a) one, the corresponding Total- $\mathrm{BaP}_{\mathrm{eq}}$ concentration of the former $\left(671 \pm 201 \mathrm{ng} \mathrm{L}^{-1}\right)$ was smaller than that of the latter $\left(987 \pm 187 \mathrm{ng} \mathrm{L}^{-1}\right)$, because the concentrations HMW-PAHs with greater corresponding TEFs were lower in the anode effluent than in the cathode one. Nevertheless, the Total- $\mathrm{BaP}_{\text {eq }}$ concentrations at $60^{\circ} \mathrm{C}$ were significantly greater than those at $80^{\circ} \mathrm{C}$.

\section{Emission Factors of Different Operating Conditions}

Table 1 summarizes the emission factors (EFs) of liquidphase Total-PAHs and Total-BaP ${ }_{\text {eq }}$ for the anode and cathode effluents and their sums under different methanol flowrates and concentrations, oxygen flowrates, and cell temperatures. The EFs of Total-PAHs of anode methanol effluent, cathode water effluent, and (anode + cathode) were $0.03 \pm 0.03,0.03 \pm 0.01$, and $0.06 \pm 0.03 \mu \mathrm{g}$ g-electrode $^{-1}$,

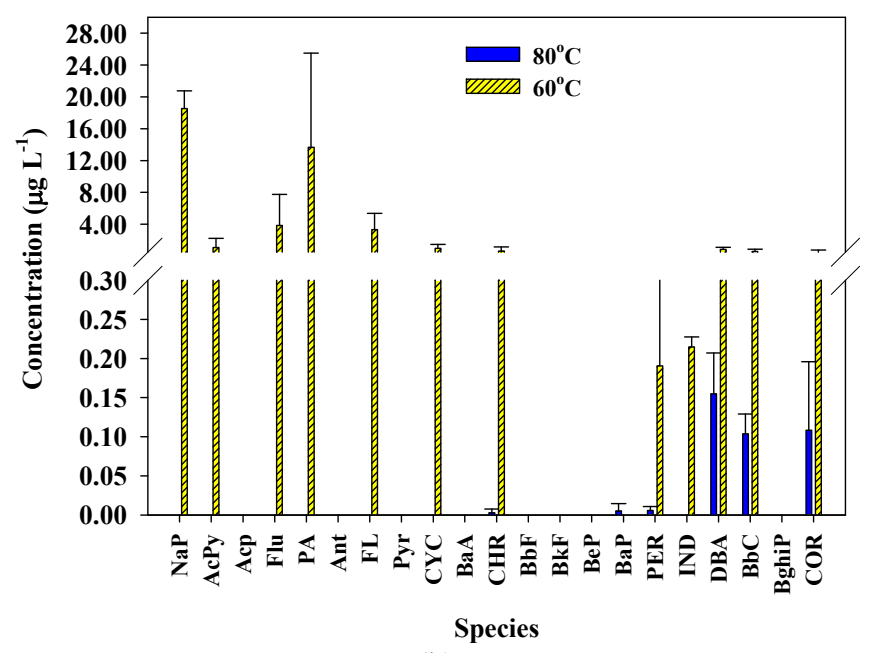

(b)

Fig. 8. Characteristic profiles of (a) anode and (b) cathode water-phase PAHs emitted from the DMFC at different cell temperatures $\left(80^{\circ} \mathrm{C}\right.$ and $\left.60^{\circ} \mathrm{C}\right)$ (methanol flowrate $=2 \mathrm{~mL} \mathrm{~min}^{-1}$, methanol concentration $=2 \mathrm{M}$, and $\mathrm{O}_{2}$ flowrate $=$ $\left.150 \mathrm{~mL} \mathrm{~min}^{-1}\right)(\mathrm{n}=3)$.

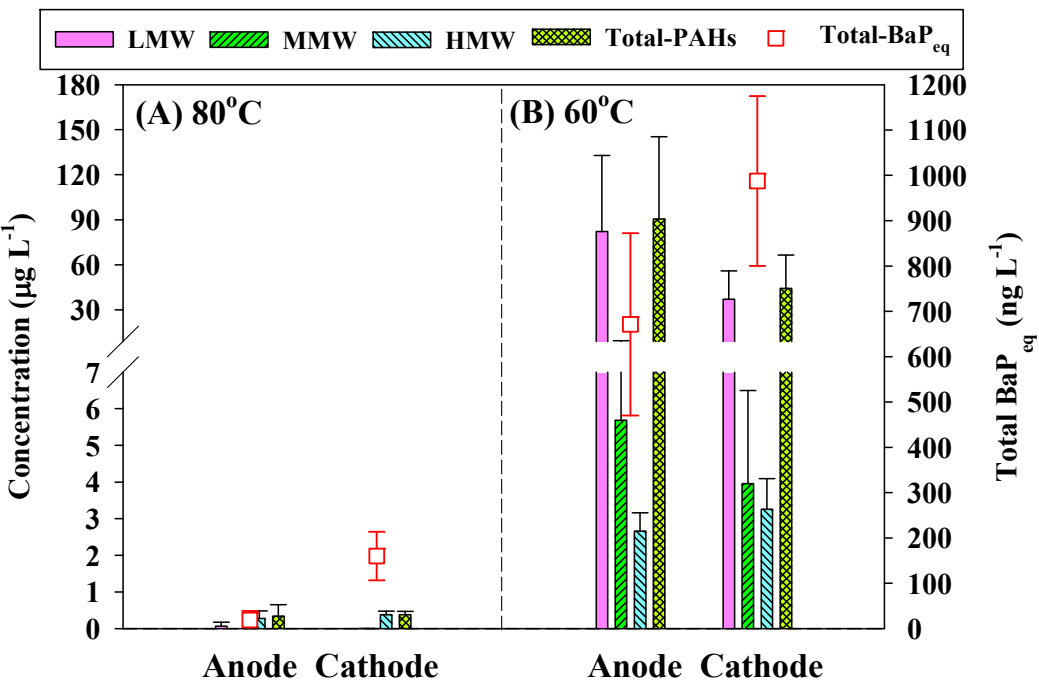

Fig. 9. Concentrations of water-phase LMW-, MMW-, HMW-, and Total-PAHs and Total-BaP ${ }_{\text {eq }}$ of anode and cathode at different cell temperatures ((a) $80^{\circ} \mathrm{C}$ and (b) $\left.60^{\circ} \mathrm{C}\right)(\mathrm{n}=3)$. 
respectively at $80^{\circ} \mathrm{C}$, methanol solution $=2 \mathrm{M}$, methanol flowrate $=2 \mathrm{~mL} \mathrm{~min}^{-1}$, and oxygen flowrate $=150 \mathrm{~mL} \mathrm{~min}^{-1}$. The corresponding data were $0.06 \pm 0.03,0.01 \pm 0.00$, and $0.07 \pm 0.03 \mu \mathrm{g}$ g-electrode ${ }^{-1}$, respectively, as the oxygen flowrate decreased from 150 to $100 \mathrm{~mL} \mathrm{~min}^{-1}$. However, these EFs increased when increasing methanol flowrate, methanol concentration, and cell temperature (sum $=3.41$ $\pm 0.86,3.29 \pm 1.03$, and $2.87 \pm 1.34 \mu \mathrm{g}$ g-electrode ${ }^{-1}$, respectively). Accordingly, the DMFC is suggested to run at the standard test condition, which is typical for DMFC operation, to achieve the lowest liquid-phase Total-PAHs emission and appropriate cell performance.

The EFs of Total-BaP $\mathrm{Bq}_{\mathrm{eq}}$ of anode methanol effluent, cathode water effluent, and sum (anode + cathode) were $1.61 \pm 1.65,14.1 \pm 4.72$, and $15.7 \pm 5.00 \mathrm{ng}$ g-electrode $^{-1}$, respectively at $80^{\circ} \mathrm{C}$, methanol solution $=2 \mathrm{M}$, methanol flowrate $=2 \mathrm{~mL} \mathrm{~min}^{-1}$, and oxygen flowrate $=150 \mathrm{~mL} \mathrm{~min}^{-1}$. This tendency is different from that of their corresponding Total-PAHs, which is primarily attributable to the significantly lower concentration of DBA $(\mathrm{TEF}=1)$ in anode effluent (ND) than in cathode one $\left(0.155 \pm 0.052 \mathrm{ng} \mathrm{L}^{-1}\right)$. Again, the corresponding data decreased $(0.90 \pm 0.52,0.01$ \pm 0.00 , and $0.91 \pm 0.52 \mathrm{ng}$ g-electrode ${ }^{-1}$, respectively) when the oxygen flowrate decreased. The EFs of Total-BaP $\mathrm{Bq}_{\text {eq }}$ anode methanol effluent, cathode water effluent, and their sum varied when increasing methanol flowrate and concentration; however, these data all increased as the cell temperature decreased $(13.4 \pm 4.02,19.8 \pm 3.75$, and 33.2 $\pm 5.50 \mathrm{ng}$ g-electrode ${ }^{-1}$, respectively). Among the different operating conditions, D and E cases exhibited the lowest and greatest EFs of sum, respectively. However, it is inappropriate for the direct comparison of the EFs obtained in this study with those of fuel consumption or driving distance (mileage) based data reported in literature. However, the emission factor based power generation can be considered in comparison to those of other power generation facilities, although the emission concentration of liquid-phase Total-PAHs of a DMFC might probably decrease to ND after its operation for few days.

\section{CONCLUSIONS}

In this study, the concentrations of PAHs in anode and cathode effluents were from ND to $0.143 \pm 0.111$ and ND to $0.155 \pm 0.052 \mu \mathrm{g} \mathrm{L}^{-1}$, respectively, when the cell was operated at the standard test condition. The anode and cathode effluents had similar Total-PAHs concentrations $\left(0.343 \pm 0.310\right.$ and $0.381 \pm 0.093 \mu \mathrm{g} \mathrm{L}^{-1}$, respectively), while the Total-BaP ${ }_{\text {eq }}$ concentration of the former (19.2 \pm $19.6 \mathrm{ng} \mathrm{L}^{-1}$ ) was significantly lower than that of the latter $\left(160 \pm 54 \mathrm{ng} \mathrm{L}^{-1}\right)$.

When changing one of the mentioned operating parameters, several LMW- and MMW-PAH species were detected, and among them, NaP exhibited the highest concentration, except the operation at $100 \mathrm{~mL} \mathrm{~min}^{-1}$. The concentrations of MW classified PAHs in anode and cathode effluents varied with the order LMW- > MMW- > HMW-PAHs at methanol concentration $=4 \mathrm{M}$ or cell temperature $=60^{\circ} \mathrm{C}$. The Total-PAHs concentrations in anode effluent ranged from $0.343 \pm 0.310$ (standard test condition) to $90.5 \pm 54.8\left(60^{\circ} \mathrm{C}\right) \mu \mathrm{g} \mathrm{L}^{-1}$, while those in cathode effluent were from $0.196 \pm 0.073$ (oxygen flowrate $\left.=100 \mathrm{~mL} \mathrm{~min}^{-1}\right)$ to $44.3 \pm 22.2\left(60^{\circ} \mathrm{C}\right) \mu \mathrm{g} \mathrm{L} \mathrm{L}^{-1}$. The corresponding Total- $\mathrm{BaP}_{\text {eq }}$ concentrations were from 12.5 \pm 7.2 (oxygen flowrate $=100 \mathrm{~mL} \mathrm{~min}^{-1}$ ) to $865 \pm 377$ (methanol flowrate $=10 \mathrm{~mL} \mathrm{~min}^{-1}$ ) and from $0.181 \pm 0.052$ (oxygen flowrate $=100 \mathrm{~mL} \mathrm{~min}^{-1}$ ) to $987 \pm 187\left(60^{\circ} \mathrm{C}\right) \mathrm{ng} \mathrm{L}^{-1}$ in anode and cathode effluents, respectively.

The sums of anode and cathode EFs for liquid-phase TotalPAHs and Total-BaP eq $_{\text {were }} 0.06 \pm 0.03 \mu \mathrm{g}_{\text {g-electrode }}{ }^{-1}$ and $15.7 \pm 5.00 \mathrm{ng}$ g-electrode ${ }^{-1}$, respectively, at the standard test condition. The Total-PAHs EF sum ranging between $0.06 \pm 0.03$ and $3.41 \pm 0.86 \mu \mathrm{g}$ g-electrode ${ }^{-1}$, increased when increasing methanol flowrate and methanol concentration or decreasing cell temperature, while the Total-BaP $\mathrm{eq}_{\mathrm{EF}}$ sum ranging from $0.91 \pm 0.52$ to $33.2 \pm 5.50 \mathrm{ng}$ g-electrode $^{-1}$, increased with increasing methanol flowrate or decreasing cell temperature and decreased with increasing methanol concentration or decreasing oxygen flowrate.

\section{ACKNOWLEDGEMENT}

The authors would like to thank the Ministry of Science and Technology, Taiwan, R.O.C. for financially supporting this research under Grant Nos. MOST 96-2211-E-020-011MY2 and 106-2221-E-020-003-MY3.

\section{REFERENCES}

Bahrami, H. and Faghri, A. (2013). Review and advances of direct methanol fuel cells: PART II: Modeling and numerical simulation. J. Power Sources 230: 303-320.

Cheruiyot, N.K., Lee, W.J., Mwangi, J.K., Wang, L.C., Lin, N.H., Lin, Y.C., Cao, J., Zhang, R. and ChangChien, G.P. (2015). An overview: Polycyclic aromatic hydrocarbon emissions from the stationary and mobile sources and in the ambient air. Aerosol Air Qual. Res. 15: 2730-2762.

Dat, N.D., Lyu, J.M. and Chang, M.B. (2018). Variation of atmospheric PAHs in northern Taiwan during winter and summer seasons. Aerosol Air Qual. Res. 18: 1019-1031.

ENVIRO Wiki (2017). Polycyclic Aromatic Hydrocarbons (PAHs). http://www.environmentalrestoration.wiki/index. php?title=Polycyclic_Aromatic_Hydrocarbons_(PAHs). Last Access: 10 July 2017.

Falcão, D.S., Oliveira, V.B., Rangel, C.M. and Pinto, A.M.F.R. (2014). Review on micro-direct methanol fuel cells. Renewable Sustainable Energy Rev. 34: 58-70.

Fan, Z.L., Chen, X.C., Lui, K.H., Ho, S.S.H., Cao, J.J., Lee, S.C., Huang, H. and Ho, K.F. (2017). Relationships between outdoor and personal exposure of carbonaceous species and polycyclic aromatic hydrocarbons (PAHs) in fine particulate matter $\left(\mathrm{PM}_{2.5}\right)$ at Hong Kong. Aerosol Air Qual. Res. 17: 666-679.

Horák, J., Kuboňová, L., Krpec, K., Hopan, F., Kubesa, P., Koloničný, J. and Plachá, D. (2018). A comparison of $\mathrm{PAH}$ emission sampling methods (cyclone, impactor) in particulate and gaseous phase. Aerosol Air Qual. Res. 
18: 849-855.

Huang, K.L., Lai, Y.C. and Tsai, C.H. (2006). Effects of sputtering parameters on the performance of electrodes fabricated for proton exchange membrane fuel cells. $J$. Power Sources 156: 224-231.

Huang, K.L., Tsai, T.H., Tsai, J.H., Chen, S.J., and Lee, W.J. (2015). Emission of PAHs from a single hydrogenoxygen PEM fuel cell: In relation to fuel cell carbon materials. Aerosol Air Qual. Res. 15: 2654-2667.

Huang, K.L., Wu, M.S., Tsai, J.H., Lin, D.Y., Chen, S.J. and Lee, W.J. (2016). Effect of operating conditions on PAHs emission from a single $\mathrm{H}_{2}-\mathrm{O}_{2}$ PEM fuel cell. Aerosol Air Qual. Res. 16: 2186-2197.

Huang, K.L., Tsai, T.H., Chen, S.J., Chao, H.R., Kuo, Y.M. and Tsai, J.H. (2018). Gas- and water-phase PAHs emitted from a single hydrogen-oxygen PEM fuel cell. Aerosol Air Qual. Res. 18: 2654-2667.

Jiang, P., Yang, L., Chen, X., Gao, Y., Li, Y., Zhang, J., Zhao, T., Yu, H. and Wang, W. (2018). Impact of dust storms on NPAHs and OPAHs in $\mathrm{PM}_{2.5}$ in Jinan, China, in spring 2016: Concentrations, health risks, and sources. Aerosol Air Qual. Res. 18: 471-484.

Jiang, R. and Chu, D. (2002). $\mathrm{CO}_{2}$ crossover through a Nafion membrane in a direct methanol fuel cell. Electrochem. Solid-State Lett. 5: A156-A159.

Joghee, P., Malik, J.N., Pylypenko, S. and O'Hayre, R. (2015). A review on direct methanol fuel cells - In the perspective of energy and sustainability. MRS Energy Sustain. 2: 1-31.

Kah, M., Zhang, X., Jonker, M.T. and Hofmann, T. (2011) Measuring and modeling adsorption of PAHs to carbon nanotubes over a six order of magnitude wide concentration range. Environ. Sci. Technol. 45: 60116017.

Kim, S., Jang, S., Kim, S.M., Ahn, C.Y., Hwang, W., Cho, Y.H., Sung, Y.E. and Choi, M. (2017). Reduction of methanol crossover by thin cracked metal barriers at the interface between membrane and electrode in direct methanol fuel cells. J. Power Sources 363:153-160.

Lai, Y.C., Huang, K.L., Tsai, C.H., Lee, W.J. and Chen, Y.L. (2012). Sputtered Pt loadings of membrane electrode assemblies in proton exchange membrane fuel cells. Int. J. Energy Res. 32: 918-927.

Lai, Y.C., Tsai, C.H., Chen, Y.L. and Chang-Chien, G.P. (2017). Distribution and sources of atmospheric polycyclic aromatic hydrocarbons at an industrial region in Kaohsiung, Taiwan. Aerosol Air Qual. Res. 17: 776787.

Lee, D. and Lee, D.G. (2016). Carbon composite bipolar plate for high-temperature proton exchange membrane fuel cells (HT-PEMFCs). J. Power Sources 327: 119126.

Lee, J.J., Huang, K.L., Yu, Y.Y. and Yang, S.C. (2004). Laboratory retention of vapor-phase PAHs using XAD adsorbents. Atmos. Environ. 38: 6185-6193.

Li, X. and Faghri, A. (2013). Review and advances of direct methanol fuel cells (DMFCs) Part I: Design, fabrication, and testing with high concentration methanol solutions. J. Power Sources 226: 223-240.
Li, Y.Y., Yang, L.X., Chen, X.F., Gao, Y., Jiang, P., Zhang, J.M., Yu, H. and Wang, W.X. (2017). PM $_{2.5}$-bound PAHs in indoor and outdoor of hotels in urban and suburban of Jinan, China: Concentrations, sources, and health risk impacts. Aerosol Air Qual. Res. 17: 2463-2473.

Li, Z., Fan, L., Wang, L., Ma, H., Hu, Y., Jiang, Y., An, C., Liu, A., Han, J. and Jin, H. (2018). PAH profiles of emitted ashes from indoor biomass burning across the Beijing-Tianjin-Hebei region and implications on source identification. Aerosol Air Qual. Res. 18: 749-761.

Mansor, M., Timmiati, S.N., Lim, K.L., Wong, W.Y., Kamarudin, S.K. and Kamarudin, N.H.N. (2019). Recent progress of anode catalysts and their support materials for methanol electrooxidation reaction. Int. J. Hydrogen Energy 44: 14744-14769.

Nisbet, C. and LaGoy, P. (1992). Toxic equivalency factors (TEFs) for polycyclic aromatic hydrocarbons (PAHs). Regul. Toxicol. Pharm. 16: 290-300.

Reizer, E., Csizmadia, I.G., Palotás, A.B., Viskolcz, B. and Fiser, B. (2019). Formation mechanism of benzo(a)pyrene: One of the most carcinogenic polycyclic aromatic hydrocarbons (PAH). Molecules 24: 1-12.

Richter, H. and Howard, J.B. (2000). Formation of polycyclic aromatic hydrocarbons and their growth to soot-A review of chemical reaction pathways. Prog. Energy Combust. Sci. 26: 565-608.

Saha, M., Maharana, D., Kurumisawa, R., Takada, H., Yeo, B.G., Rodrigues, A.C., Bhattacharya, B., Kumata, H., Okuda, T., He, K., Ma, Y., Nakajima, F., Zakaria, M.P., Giang, D.H. and Viet, P.H. (2017). Seasonal trends of atmospheric PAHs in five Asian megacities and source detection using suitable biomarkers. Aerosol Air Qual. Res. 17: 2247-2262.

Tenson, T.J. and Baby, R. (2017). Recent advances in proton exchange membrane fuel cells: A review. IJARSET 4: 34-40.

Tiwari, J.N., Tiwari, R.N., Singh, G. and Kim, K.S. (2013). Recent progress in the development of anode and cathode catalysts for direct methanol fuel cells. Nano Energy 2: 533-578.

Tran, P.D., Morozan, A., Archambault, S., Heidkamp, J., Chenevier, P., Dau, H., Fontecave, M., Martinent, A., Jousselme B. and Artero, V. (2015). A noble metal-free proton-exchange membrane fuel cell based on bioinspired molecular catalysts. Chem. Sci. 6: 2050-2053.

Wang, J., Guinot, B., Dong, Z., Li, X., Xu, H., Xiao, S., Ho, S.S.H., Liu, S. and Cao, J. (2017). $\mathrm{PM}_{2.5}$-bound polycyclic aromatic hydrocarbons (PAHs), oxygenatedPAHs and phthalate esters (PAEs) inside and outside middle school classrooms in Xi'an, China: Concentration, characteristics and health risk assessment. Aerosol Air Qual. Res. 17: 1811-1824.

Wasmus, S., Wang, J.T. and Savinell, R.F. (1995). Realtime mass spectrometric investigation of the methanol oxidation in a direct methanol fuel cell. J. Electrochem. Soc. 14: 3825-3833.

Wasmus, S. and Küver, A. (1999). Methanol oxidation and direct methanol fuel cells: A selective review. $J$. Electroanal. Chem. 461: 14-31. 
Wright, L.P., Zhang, L., Cheng, I., Aherne, J. and Wentworth, G.R. (2018). Impacts and effects indicators of atmospheric deposition of major pollutants to various ecosystems - A review. Aerosol Air Qual. Res. 18: 19531992.

Xu, S., Chen, T., Li, X., Yan, J. and Cen, K. (2018). Behavior of PCDD/Fs, PCBs, CBzs and PAHs during thermal treatment of various fly ash from steel industry. Aerosol Air Qual. Res. 18: 1008-1018.

Zeis, R. (2015). Materials and characterization techniques for high-temperature polymer electrolyte membrane fuel cells. Beilstein J. Nanotechnol. 6: 68-83.

Zhang, N., Cao, J., Li, L., Ho, S.S.H., Wang, Q., Zhu, C. and Wang, L. (2018). Characteristics and source identification of polycyclic aromatic hydrocarbons and $n$-alkanes in $\mathrm{PM}_{2.5}$ in Xiamen. Aerosol Air Qual. Res. 18: $1673-1683$.

Received for review, August 1, 2019 Revised, August 16, 2019 Accepted, August 27, 2019 